[Agr. Biol. Chem., Vol. 35, No. 2, p. 248 254, 1971]

\title{
Number and Reactivity of the Sulfhydryl Groups of Potato Phosphorylase ${ }^{\dagger}$
}

\author{
By Atsumi Kamogawa, Toshio FukUI and Ziro NikUni ${ }^{\top}$ \\ The Institute of Scientific and Industrial Research, \\ Osaka University, Suita, Osaka \\ Received July 17, 1970
}

\begin{abstract}
The number and reactivity of the sulfbydryl ( $\mathrm{SH}$ ) groups of potato phosphorylase [EC 2.4.1.1] were investigated, in comparison to those groups in muscle phosphorylase $b$. Potato phosphorylase was found to contain 17.2 moles of total half-cystine residues per $200,000 \mathrm{~g}$ of protein; all of which seemed to exist in the form of the SH group. Reactivity of $\mathrm{SH}$ groups in the native state with various $\mathrm{SH}$ reagents was low. Inactivation with $p$ chloromercuribenzoate and iodoacetamide proceeded gradually. No inactivation was observed with 5, 5'-dithiobis-(2-nitrobenzoic acid), $N$-ethylmaleimide and iodoacetic acid. The enzyme apparently did not dissociate into subunits upon reacting with $\mathrm{SH}$ reagents. The difference in quarternary structure may be directly related to differing control mechanisms in potato and rabbit muscle phosphorylases, although their other properties are surprisingly similar.
\end{abstract}

Phosphorylase is widely distributed in animal and plant tissues, and plays an important role in the metabolism of starch and glycogen. The enzyme from rabbit muscle has been well characterized as an allosteric protein. It exists in two forms; phosphorylase $b$, dimer, which is active only in the presence of AMP, and phosphorylase $a$, tetramer, which is active in the absence of this nucleotide. These two forms are readily interconvertible through enzymatic phosphorylation and dephosphorylation of their specific serine residues. Phosphorylase from potato tuber differs from the muscle enzyme in the control mechanism of its enzymatic activity; the potato enzyme requires no AMP for enzymatic activity and has no specific serine residue to be phosphory-

$\dagger$ In this report, phosphorylase refers to $\alpha$-glucan (glycogen and starch) phosphorylase $[\alpha-1,4-$ glucan: orthophosphate glucosyltransferase, EC 2.4.1.1]. Abbreviations used are: DTNB, 5,5'-dithiobis-(2-nitrobenzoic acid); PCMB, p-chloromercuribenzoic acid; SDS, sodium dodecyl sulfate; SH, sulfhydryl.

* Present address: Hayashi Gakuen Women's College, Konan, Aichi. lated. Potato phosphorylase and muscle phosphorylase $b$, however, resemble each other in molecular weight, ${ }^{1 "}$ amino acid composition, ${ }^{21}$ the content and binding mode of pyridoxal $5^{\prime}$-phosphate ${ }^{3,41}$ and their circular dictro ism spectra. ${ }^{\tilde{i}}$

Although little was known of the active site of phosphorylase, a previous paper ${ }^{6}$ showed that small numbers of arginine and/or lysine residues were directly involved in the function of enzymes from both potato tuber and rabbit muscle, by using glyoxal as a modifying reagent. The importance of $\mathrm{SH}$ groups in the structure and function of muscle phosphorylase has long been recognized. ${ }^{7-14}$ Participation

1) Ya-Pin Lee, Biochim. Biophys. Acta, 43, 18 (1960).

2) A. Kamogawa, T. Fukui and Z. Nikuni, $J$. Biochem., 63, 361 (1968).

3) Ya-Pin Lee, Biochim. Biophys. Acta, 43, 25 (1960).

4) A. Kamogawa, ibid., 178, 459 (1969).

5) A. Kamogawa, T. Fukui and Z. Nikuni, J. Biochem., 64, 709 (1968).

6) T. Fukui, A. Kamogawa and Z. Nikuni, ibid., Biochem., 67, 211 (1970).

7) N. B. Madsen and C. F. Cori, J. Biol. Chem., 223, 1055 (1956). 
of these groups in the subunit interaction and allosteric transition of rabbit muscle phosphorylase $b$ was recently studied by Kastenschmidt et al. ${ }^{131}$ Our attention was directed, in connection with the previous studies, to $\mathrm{SH}$ groups of potato phosphorylase in order to determine the active site of the enzyme and the complicated regulatory mechanism of muscle phosphorylase. The present paper describes number and reactivity of the $\mathrm{SH}$ groups of potato phosphorylase with various $\mathrm{SH}$ reagents. The results were discussed in relation to the role of SH groups in the potato enzyme and also in comparison with those of rabbit muscle phosphorylase $b$.

\section{MATERIALS AND METHODS}

Chemicals Glucose 1-phosphate (dipotassium salt) was purchased from Sigma. DTNB and $N$ methyl maleimide were obtained from Nakarai. PCMB, iodoacetic acid, iodoacetamide, SDS, urea and guanidine hydrochloride were products of Wako. Iocoacetamide-1-14 C was purchased from the Radiochemical Centre, Amersham.

Enzyme. Crystalline potato phosphorylase was prepared according to the method described previously. ${ }^{2}$ Concentration of the enzyme was determined either according to the method of Lowry et al., ${ }^{15}$ using bovine serum albumin as the standard, or spectrophotometrically from the absorbance at $280 \mathrm{~m} \mu$ with the $E_{1 \mathrm{~cm}}^{1 \%}$ value of 11.7

Assay of phosphorylase activity. Enzymatic activity

8) I. Jokay, S. Damjanovich and S. Toth, Arch. Biochem. Biophys., 112, 471 (1965).

9) A. Kudo and R. Shukuya, J. Biochem., 55, 254 (1964).

10) S. Damjanovich and K. Kleppe, Biochem. Biophys. Res. Commun., 26, 65 (1967).

11) A. M. Gold, Biochemistry, 7, 2106 (1968).

12) M. L. Battel, L. B. Smillie and N. B. Madsen, Can. J. Biochem., 46, 609 (1968).

13) K. L. Kastenschmidt, J. Kastenschmidt and E. Helmreich, Biochemist ry, 7, 3590 (1968).

14) K. Kleppe and S. Damjanovich, Biochim. Biophys. Acta, 185, 88 (1969).

15) O. H. Lowry, N. J. Rosenbrough, A. L. Farr and R. J. Randall, J. Biol. Chem., 193, 265 (1951). was assayed by determining the amounts of $P_{1}$ liberated from glucose 1-phosphate in the presence of soluble starch. The reaction mixture contained 5 to $10 \mu \mathrm{l}$ of the enzyme solution (about $1 \mathrm{mg} / \mathrm{ml}$ ), $0.2 \mathrm{ml}$ of $0.5 \mathrm{M}$ citrate buffer ( $\mathrm{pH} 6.0$ ) $0.2 \mathrm{ml}$ of $5 \%$ soluble starch, $0.1 \mathrm{ml}$ of $0.1 \mathrm{M}$ glucose 1-phosphate and water in a total volume of $1 \mathrm{ml}$. The reaction was started by the addition of glucose 1-phosphate. After incubation for $10 \mathrm{~min}$ at $30^{\circ} \mathrm{C}$, the reaction was stopped by add. ing $0.5 \mathrm{ml}$ of $5 \%$ trichloroacetic acid, then 0.2 to $0.5 \mathrm{ml}$ of the resulting solution was taken for analysis of $P_{1}$ by the method of Fiske and Subbarow. ${ }^{16}$

Determination of total half-cystine content. Total half. cystine content was determined by the performic acid. oxidation method.17) The enzyme solution $(0.5 \mathrm{ml}$ containing $12.5 \mathrm{mg}$ ) in $1 \mathrm{mM}$ citrate buffer $(\mathrm{pH} 6.0$ was kept for $4 \mathrm{hr}$ at $0^{\circ} \mathrm{C}$ with $10 \mathrm{ml}$ of freshly prepared performic acid. The reaction was stopped by diluting it with water and the solution was lyophiliz ed. The dried sample was hydrolyzed in $6 \mathrm{~N} \mathrm{HCl}$ for $24 \mathrm{hr}$ at $110^{\circ} \mathrm{C}$ in a sealed evacuated tube. Aminc acid content of the hydrolyzate was analyzed on a Beckman/Spinco Model MS amino acid analyzer. Th number of moles of each amino acid was calculatec on the bases of the values for leucine and alanint described in a previous paper. ${ }^{2}$

Reaction with DTNB. The reaction of DTNB with the $\mathrm{SH}$ groups of potato phosphorylase was carriec out according to Ellman. ${ }^{18}$. The enzyme was incubat ed with $0.6 \mathrm{~mm} \mathrm{DTNB}$ in $1 \mathrm{ml}$ of $10 \mathrm{mM}$ citrate buf fer $\left(\mathrm{pH} 6.0\right.$ ) at $20^{\circ} \mathrm{C}$ in the absence or presence of denaturating agents. The reaction was started by add ing the enzyme, which was followed by an increase in absorbance at $412 \mathrm{~m} \mu$. The molar extinction co efficient value of 13,600 was used to calculate the number of $\mathrm{SH}$ groups which reacted. At various tim. intervals, $10 \mu \mathrm{l}$ aliquots of the reaction mixture wa. removed for assay of enzymatic activity.

Reaction with PCMB. The reaction of $\mathrm{PCMB}$ witl the $\mathrm{SH}$ groups of potato phosphorylase was carriec out according to Boyer. ${ }^{19 /}$ The reaction mixture con tained the enzyme $(4.1 \mu \mathrm{M})$ and various concentration

16) C. Fiske and Y. Subbarow, J. Biol. Chem., 66 375 (1925).

17) S. Moore, ibid., 238, 235 (1963).

18) G. L. Ellman, Arch. Biochem. Biophys., 82, 7 (1959).

19) P. D. Boyer, J. Am. Chem. Soc., 76, 4331 (1954) 
of PCMB in $1.0 \mathrm{ml}$ of $20 \mathrm{mM}$ glycerophosphate buffer $(\mathrm{pH} 6.8)$, and this was incubated at $20^{\circ} \mathrm{C}$. The reaction was started by adding the enzyme. This was followed by an increase in absorbance at $250 \mathrm{~m} \mu$. The blank used contained the same reaction mixture omitting the enzyme. Absorbance due to the enzyme was subtracted from the observed value. The concentration of PCMB was calculated from the absorbance at $232 \mathrm{~m} \mu$ under the same conditions as above, using the molar extinction coefficient value of 17,400. After incubation for 3 and $20 \mathrm{hr}, 10 \mu \mathrm{l}$ aliquots of the reaction mixtures were withdrawn for assay of enzymatic activity.

Incorporation of iodoacetamide-1-14 $C$. The enzyme $(48 \mu \mathrm{M})$ was incubated with $10 \mathrm{mM}$ iodoacetamide-1-14C $(8850 \mathrm{cpm})$ in $1 \mathrm{ml}$ of $30 \mathrm{mM}$ glycerophosphate buffer $(\mathrm{pH} 7.5)$ at $30^{\circ} \mathrm{C}$. At various time intervals, $0.1 \mathrm{ml}$ aliquots of the reaction mixture were transferred into $2.5 \mathrm{ml}$ of $5 \%$ trichloroacetic acid in a filter funnel equipped with a Millipore filter (GS $0.22 \mu$ ). The precipitate formed was collected by suction on the Millipore filter and was washed with $10 \mathrm{ml}$ of $5 \%$ trichloroacetic acid. The precipitate on the filter was dried under a heating lamp, and its radioactivity was determined with an Aloka gas-flow counter. The other $10 \mu 1$ aliquots taken at the same time were used to assay enzymatic activity.

When adding denaturating agents, the enzyme $(24 \mu \mathrm{M})$ was incubated with $5 \mathrm{mM}$ iodoacetamide $(8850 \mathrm{cpm})$ and either $8 \mathrm{M}$ urea or $10 \% \mathrm{SDS}$ in $2.0 \mathrm{ml}$ of $30 \mathrm{mM}$ glycerophosphate buffer $(\mathrm{pH} 7.5)$ at $30^{\circ} \mathrm{C}$. At various time intervals, $0.2 \mathrm{ml}$ aliquots of the reaction mixture were taken for the determination of radioactivity as above.

Preparation and gel filtration of the PCMB- and iodoacetamide-treated enzymes. The PCMB-treated enzyme was prepared by incubating the enzyme $(5.4 \mathrm{mg})$ at $30^{\circ} \mathrm{C}$ with $80 \mu \mathrm{M}$ of $\mathrm{PCMB}$ in $10 \mathrm{ml}$ of $10 \mathrm{mM}$ glycerophosphate buffer $(\mathrm{pH} 6.8)$ for $200 \mathrm{~min}$. The reaction mixture was concentrated and an aliquot of the concentrated solution was applied to a column of Sephadex G-150 $(1.5 \times 86 \mathrm{~cm})$ equilibrated with $5 \mathrm{~mm}$ citrate buffer $(\mathrm{pH} \mathrm{6.0)}$. Protein was eluted with the same buffer. Fractions of $2.4 \mathrm{ml}$ each were collected and used for measuring absorbancy at $280 \mathrm{~m} \mu$. The iodoacetamide-treated enzyme was prepared by incubating the enzyme $(9 \mathrm{mg})$ at $30^{\circ} \mathrm{C}$ with $10 \mathrm{mM}$ iodoacetamide in $1.0 \mathrm{ml}$ of $30 \mathrm{mM}$ glycerophosphate buffer ( $\mathrm{pH} 7.5$ ) for $22.5 \mathrm{hr}$. The procedures which followed were the same as above. The native enzyme was chromatographed in the same manner as the standard.

Others. For the molecular weight of potato phosphorylase, Lee ${ }^{11}$ reported the value of 207,000 , based on an assumed partial specific volume value of 0.75 . This value should be regarded as an approximate one, thus the value of 200,000 was tentatively used in this study.

All spectrophotometric measurements were carried out on a Hitachi-Perkin-Elmer 139 UV/VIS Spectrophotometer.

\section{RESULTS}

\section{Half-cystine content}

The performic acid-oxidation method ${ }^{17}$ was applied to obtain the total half-cystine content of potato phosphorylase. It was found to be 17.2 moles per $200,000 \mathrm{~g}$ of protein. The half-cystine content of rabbit muscle phosphorylase $b$ varies somewhat according to different investigators; 15.7 by Sevilla and Fischer, ${ }^{201} 16.9$ by Appleman et al. ${ }^{211}$ and 17.6 by Battell et al., ${ }^{121}$ all moles per $185,000 \mathrm{~g}$ of protein. These values are sufficiently close to the present value of potato phosphorylase.

\section{Reaction with $D T N B$}

Reactivity of the $\mathrm{SH}$ groups of potato phosphorylase was first examined by their reactions with DTNB. Figure 1 shows the time course for the reaction of potato phosphorylase with DTNB $(0.6 \mathrm{mM})$ at $\mathrm{pH} 6.0$ and $20^{\circ} \mathrm{C}$ in the absence or presence of denaturating agents. In the absence of denaturating agent, no increase in absorbance at $412 \mathrm{~m} \mu$ was observed through $80 \mathrm{~min}$. This shows no release of thionitrobenzoate anion. Enzymatic activity also did not change at all during this period. Increasing the concentration of DTNB $(6 \mathrm{mM}$, corresponding to 1300 -fold molar excess) 10 -fold and incubation at $\mathrm{pH} 6.8$ still caused no increase in the absorbance at $412 \mathrm{~m} \mu$. These

20) C. L. Sevilla and E. H. Fischer, Biochemistry, 8, 2161 (1969).

21) M. M. Appleman, A. A. Yunis, E. G. Krebs and E. H. Fischer, J. Biol. Chem., 238, 1358 (1963). 


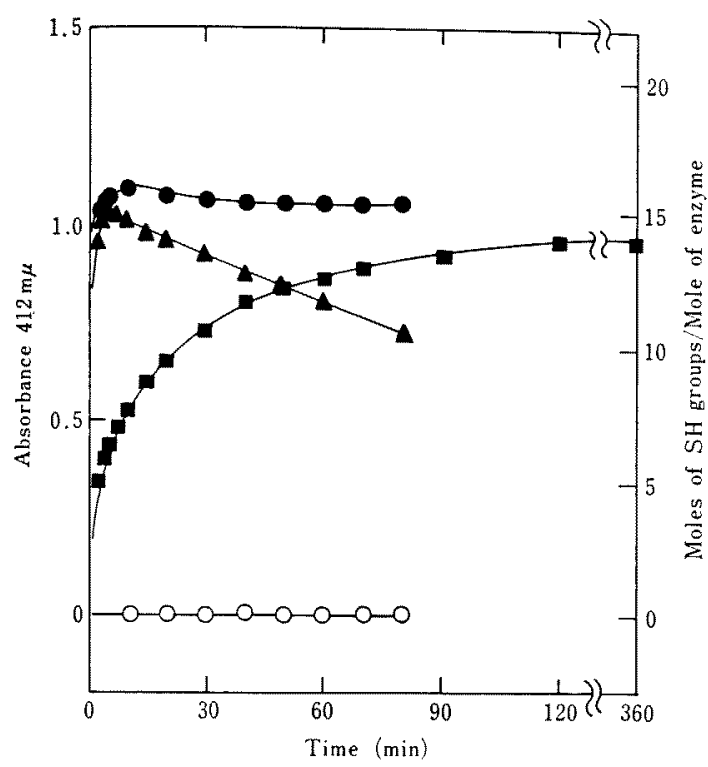

FIG. 1. Time Course of Reaction of Potato Phosphorylase with DTNB.

Enzyme concentration, $5.0 \mu \mathrm{M}$. $\mathrm{O}-\mathrm{O}$, native; - $-8 \mathrm{M}$ urea; $\boldsymbol{\Delta}-\boldsymbol{\Lambda}, 4 \mathrm{M}$ guanidine hydrochloride; $\mathbf{\square}-1 \%$ SDS.

results indicate that potato phosphorylase in its native state contains no $\mathrm{SH}$ group reactive to DTNB. In rabbit muscle phosphorylase $b$, it was shown that there are approximately 2 rapidly and 4 slowly reacting $\mathrm{SH}$ groups and that the reaction of the second class of $\mathrm{SH}$ groups was accompanied with a parallel loss of enzymatic activity. ${ }^{141}$

In the presence of $8 \mathrm{M}$ urea and $4 \mathrm{M}$ guanidine hydrochloride, the absorbance increased rapidly and reached a maximum value within a few minutes. Extrapolated absorbance values correspond to $15-16 \mathrm{SH}$ groups per $200,000 \mathrm{~g}$ of enzyme protein. The protein reacted gradually with DTNB in the presence of $1 \%$ SDS. After $2 \mathrm{hr}$, the absorbance reached a maximum value, which corresponds to $14 \mathrm{SH}$ groups. The results suggest that essentially all of the halfcystine residues might exist in the form of an $\mathrm{SH}$ group, but they are all buried in the protein molecule and are unreactive with DTNB

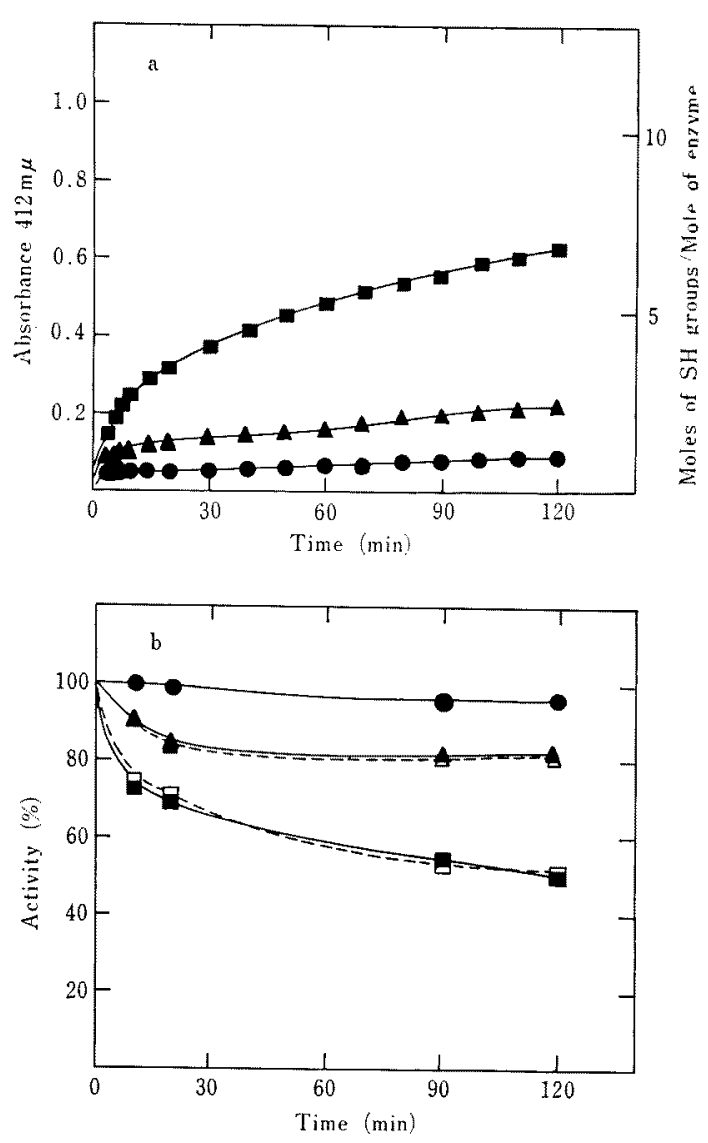

FIG. 2. Time Course of Reaction of Potato Phosphorylase with DTNB in the Presence of a Low Concentration of Urea.

a) Increase in absorbance at $412 \mathrm{~m} \mu$, b) Loss of enzymatic activity. Concentration of urea was: - $-2 \mathrm{M} ; \triangle \mathrm{\triangle}$ and $\triangle--\triangle, 3 \mathrm{M} ; \mathbf{\mathrm { D }}-\mathbf{E}$ and $\square-$. $\square$, 4M. Broken lines show the results with the control, omitting DTNB.

in the native state.

Additional experiments revealed that the reaction between potato phosphorylase and DTNB occurred even in the presence of much lower concentrations of urea than $8 \mathrm{M}$ (Fig. 2a). The reaction was accompanied with a loss of enzymatic activity (Fig. 2b). The rate of inactivation, however, depended upon the concentration of urea, and was not affected by 
the presence of DTNB. Inactivation appears to be caused by the unfolding of enzyme protein with urea, not by the reaction with DTNB.

\section{Reaction with PCMB}

Lee $^{31}$ reported that titration of potato phosphorylase with PGMB gave a value of $6.8 \mathrm{SH}$ groups per mole of enzyme in the native state. This titration was repeated in the present study with the crystalline enzyme preparation. The reaction was followed by an increase in ab-
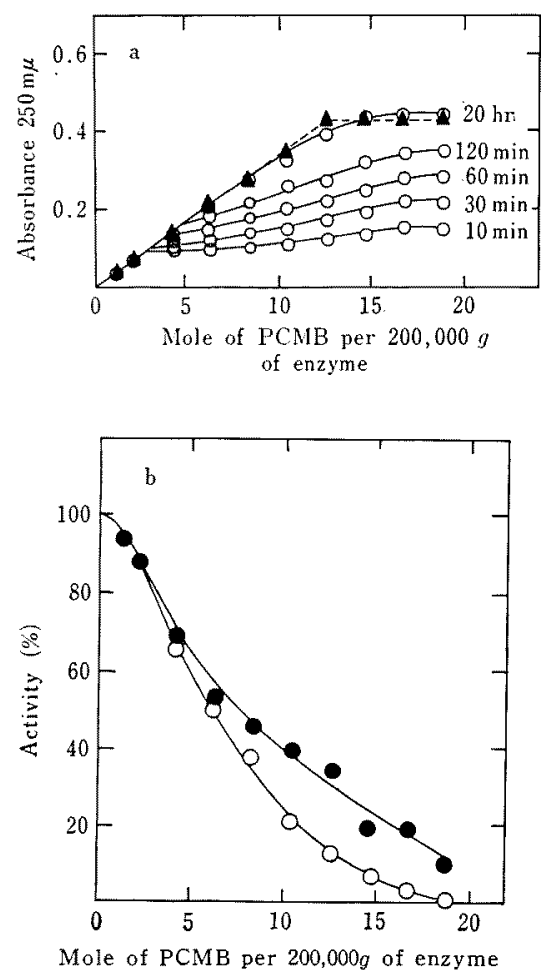

FIG. 3. Reaction of Potato Phosphorylase with $\mathrm{PCMB}$.

a) Absorbance values at $250 \mathrm{~m} / \iota$ at various time intervals shown in the numerical figures by the lines, plotted against the concentration of PCMB. The broken line shows the reaction in the presence of $1 \% \mathrm{SDS}$, with values after $12 \mathrm{~min}$ incubation being plotted. $\mathrm{O}-\mathrm{O}$, no SDS; $\mathbf{\Delta}-\cdots, 1 \%$ SDS. b) The per cent of remaining activities for the original. -e, $3 \mathrm{hr} ; \mathrm{O}-\mathrm{O}, 20 \mathrm{hr}$. sorbance at $250 \mathrm{~m} \mu$ for each reaction mixture containing varied amounts of PCMB. Figure 3 a shows the results of determinations at various time periods after mixing the enzyme with PCMB and incubating it at $\mathrm{pH} 6.8$ and $20^{\circ} \mathrm{C}$. Approximately $3 \mathrm{SH}$ groups per $200,000 \mathrm{~g}$ of protein reacted rapidly with PCMB. The remaining groups reacted much more slowly, but went almost to completion after $20 \mathrm{hr}$; without a denaturating agent. In the presence of $1 \% \mathrm{SDS}$, the increase in absorbance at 250 $\mathrm{m} \mu$ proceeded very rapidly, and reached apparent maximum values within a few minutes. The broken line in Fig. 3a indicates the results at $12 \mathrm{~min}$, which show the reaction of about $13 \mathrm{SH}$ groups per $200,000 \mathrm{~g}$ of protein. This coincides well with the results without SDS after $20 \mathrm{hr}$.

In rabbit muscle phosphorylase $b$, the number of $\mathrm{SH}$ groups reacting with PCMB is 6.9 according to Damjanovich and Kleppe ${ }^{101}$ and 6.6 according to Battell et al. ${ }^{121}$ both per $185,000 \mathrm{~g}$ protein. However, the reaction seemed incomplete under the conditions they used to determine these values. We assumed that these two values for muscle enzyme and Lee's value for potato enzyme might have been estimated too low.

Figure $3 \mathrm{~b}$ shows the remaining enzymatic activity of potato phosphorylase after 3 and $20 \mathrm{hr}$ at $20^{\circ} \mathrm{C}$ with various amounts of PCMB. The reaction of the first few $\mathrm{SH}$ groups did not cause any appreciable loss of enzymatic activity and complete inactivation was attained by incubation with $80 \mu \mathrm{M}$ PCMB (19 molar excess) for $20 \mathrm{hr}$. Inactivation proceeded very slowly and was not appreciably reversed by the addition of cysteine. The addition of glucose, glucose 1-phosphate or AMP (all $10 \mathrm{mM}$ ) did not affect the rate of inactivation with PCMB. These results suggest that the reaction of potato phosphorylase with PCMB, as well as the inactivation, proceed gradually with concomitant unfolding of the protein molecule, which may cause further reaction and inactivation. 


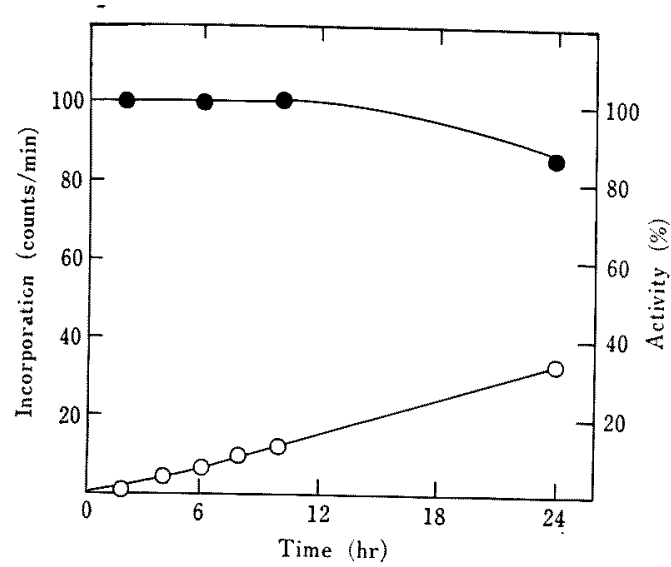

FIG. 4. Time Course of Incorporation of Iodoacetamide- $1-{ }^{14} \mathrm{C}$ into Potato Phosphorylase.

$\mathrm{O}-\mathrm{O}$, radioactivity incorporated into protein; - per cent of remaining activity in the original.

\section{Reaction with iodoacetamide}

Figure 4 shows the time courses for the incorporation of ${ }^{14} \mathrm{C}$-iodoacetamide into protein at $\mathrm{pH} 7.5$ and $30^{\circ} \mathrm{C}$, and for the decrease of enzymatic activity during this incubation. Incorporation proceeded slowly, but linearly, up to the extent of about 7 moles per $200,000 \mathrm{~g}$ of protein for $24 \mathrm{hr}$. The reaction seemed to continue even after this period of incubation. Enzymatic activity did not change while the first $3 \mathrm{SH}$ groups reacted, but decreased gradually in accordance with the reaction of the next $4 \mathrm{SH}$ groups. The remaining activity was still $85 \%$ of the original when a total of 7 moles of iodoacetamide were incorporated into protein.

In muscle phosphorylase $b$ under similar conditions, the first two $\mathrm{SH}$ groups reacted very rapidly with iodoacetamide without loss of enzymatic activity, and the next 4 reacted with progressive inactivation. ${ }^{12}$ A complete loss of enzymatic activity was attained when a total of $6 \mathrm{SH}$ groups were modified.

In the presence of $8 \mathrm{M}$ urea and 1\% SDS, ${ }^{14} \mathrm{C}$-iodoacetamide was quite rapidly incorporated into potato phosphorylase and incorporation ceased when it reached to the extent of

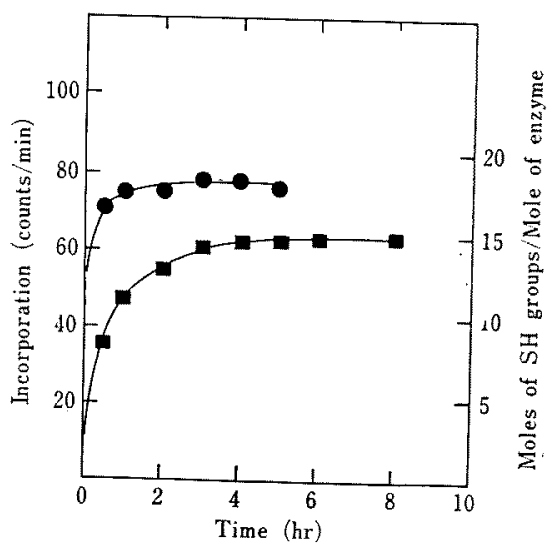

FIG. 5. Time Course of Incorporation of Iodoacetamide-1-14 C into Potato Phosphoryiase in the Presence of Denaturating Agents.

$-\bullet, 8 \mathrm{M}$ urea; $\mathbf{\square - \mathbf { v }} 1 \% \mathrm{SDS}$.

18 and 15 moles per $200,000 \mathrm{~g}$ of protein, respectively, as shown in Fig. 5.

\section{Reaction with other alkylating reagents}

Incubation of potato phosphorylase $(9 \mathrm{mg})$ with $20 \mathrm{mM} N$-ethyl maleimide at $\mathrm{pH} 7.5$ and $30^{\circ} \mathrm{C}$ did not affect enzymatic activity. A similar result was obtained by incubating it with $10 \mathrm{~mm}$ iodoacetic acid at $\mathrm{pH} 7.5$ and $30^{\circ} \mathrm{C}$.

\section{Effect of PCMB and iodoacetamide on molecular weight}

The reaction of muscle phosphorylase (both $a$ and $b$ forms) with various $\mathrm{SH}$ reagents is known to cause the dissociation of enzyme protein into monomeric subunits. ${ }^{7,12,14}$ Potato phosphorylase has been supposed to be composed of a similar subunit structure because its molecular weight is high and is close to that of the dimeric form of muscle phosphorylase $^{\text {" }}$ and it contains two bound pyridoxal-5'phosphate groups per mole of enzyme ${ }^{3 !}$ as does rabbit muscle phosphorylase $b$. To test this possibility, potato phosphorylase, incubated with either PCMB or iodoacetamide, was subjected to gel filtration on Sephadex to compare 
its molecular weight with that of the native enzyme.

As shown in Fig. 6, both treated enzymes were eluted at the same position as the native enzyme. Potato phosphorylase apparently did not dissociate into subunits upon reacting with PCMB and iodoacetamide, in contrast to muscle phosphorylase.

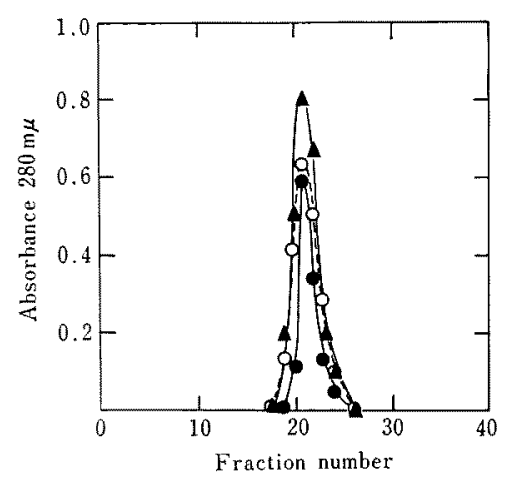

Fig. 6. Gel Filtration on Sephadex G-150 of Potato Phosphorylase Treated with PCMB and Iodoacetamide.

O-. - native enzyme;

$\Delta-\mathbf{\Delta}$, iodoacetamide-treated.

\section{DISCUSSION}

It would appear from the present study that potato phosphorylase and muscle phosphorylase $b$ contain a similar number of total halfcystine residues, all of which exist in the form of a $\mathrm{SH}$ group. Similarities between these two enzymes have been already pointed out for molecular weight, ${ }^{11}$ amino acid composition, ${ }^{21}$ the content and binding mode of pyridoxal 5'-phosphate, ${ }^{3,4}$ and their circular dichroism spectra, ${ }^{5}$ although they are quite different in the control mechanisms of their enzymatic activities.

Reactivity of $\mathrm{SH}$ groups in potato phosphorylase with various $\mathrm{SH}$ reagents were much lower than those in muscle phosphorylase $b$. The potato enzyme was completely inert to DTNB in the native state under the conditions tested. $N$-Ethyl maleimide and iodoacetic acid caused no inactivation. These results, as well as a previous observation on the state of bound pyridoxal $5^{\prime}$-phosphate, ${ }^{4}$ ' suggest that potato enzyme has a more rigid structure than muscle enzyme. This may be related to a higher content of $\alpha$-helical structure in the former than in the latter. ${ }^{5}$

The reaction and inactivation of potato phosphorylase with PCMB and iodoacetamide proceeded gradually without sudden loss of activity. Probably this inactivation is due to non-specific denaturation of the protein molecule, and not to blocking of the specific active site. Muscle phosphorylase is inactivated with these $\mathrm{SH}$ reagents in correspondence with the reaction of rather small numbers of $\mathrm{SH}$ groups and always accompanies the dissociation into subunit. ${ }^{12,141}$ The rate of inactivation of potato enzyme with a low concentration of urea was not affected by the presence of DTNB. The $\mathrm{SH}$ groups of potato phosphorylase may not be involved in the active site in this enzyme. Gold $^{11}$ and Kastenschmidt et al. ${ }^{131}$ have recently claimed that the SH groups in muscle phosphorylase $b$ are not essential to the catalytic function or to the substrate binding but are important in maintaining its quarternary structure which necessitates enzymatic activity. Potato phosphorylase, however, was not changed in its molecular weight upon reacting with PGMB and iodoacetamide, as shown in the present study. The difference in quarternary structure may be directly related to differing control mechanisms in these two enzymes, although their other properties, as far as investigated, are surprisingly similar.

Acknowledgement. The authors would like to express their gratitude to Prof. K. Narita of the Institute for Protein Research, Osaka University for amino acid analysis. 